\title{
Pengetahuan Ibu Balita Dalam Pengendalian Stunting Di Sulawesi Selatan
}

\author{
Muslimin B' ${ }^{1)}$, Abdul Gafur'), Muh.Azwar'), Dian Meiliani Yulis ${ }^{2)}$ \\ ${ }^{1)}$ UPRI Makassar \\ ${ }^{2)}$ PPS Kependudukan dan Lingkungan Hidup, Universitas Negeri Makassar \\ Email : iminkmus@yahoo.com
}

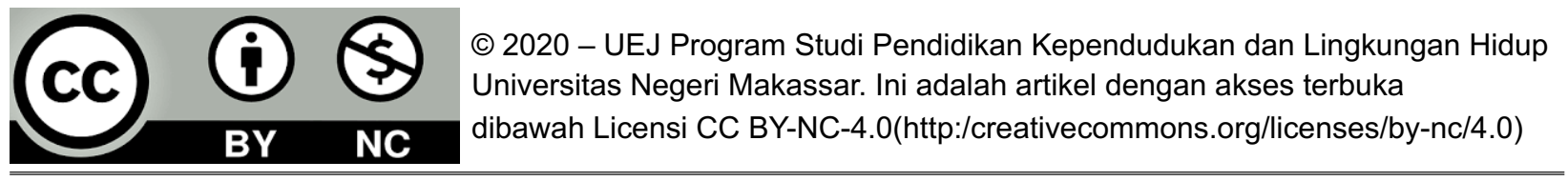

\begin{abstract}
Abstrak.
Stunting merupakan perhatian utama di Indonesia maupun pada Negara-negara lainnya dalam permasalahan kesehatan masyarakat. Masalah yang terdapat pada saat ini adalah permasalahan tentang gizi dan kesehatan ibu hamil dan menyusui serta anak usia di bawah lima tahun yang sangat erat keterkaitan pada masalah kurang gizi kronis yang disebut "stunting". Berdasarkan dari hasil kajian teori maupun beberapa penelitian yang berkaitan dengan Stunting baik di Sulawesi Selatan maupun yang ada di beberapa daerah lainnya di Indonesia. Pemenuhan gizi seorang balita, tentunya ibu memegang peranan yang sangat penting. Ibu merupakan orang yang paling dekat dengan anak dalam hal pengasuhannya, jadi ibu memiliki pengetahuan yang baik tentang gizi balita, tentunya diharapkan ibu juga akan memiliki sikap dan perilaku yang baik pula dalam pemenuhan gizi balita. Di samping konsumsi makanan status gizi juga dipengaruhi oleh sanitasi lingkungan, Kurangnya akses masyarakat terhadap air bersih atau air minum serta buruknya sanitasi dan perilaku higiene sangatlah berkontribusi terhadap gangguan kesehatan, seperti masalah gizi pada bayi dan anak balita di Indonesia disebabkan penyakit infeksi yang erat kaitannya dengan sanitasi lingkungan.dengan kejadian stunting pada balita.
\end{abstract}

Kata Kunci :Pola Asuh, Pola Makan dan Sanitasi Lingkungan.Stunting

\section{Pendahuluan}

Stunting adalah salah satu kegagalan mencapai perkembangan fisik yang diukur berdasarkan tinggi badan menurut usia. Batasan stunting yaitu tinggi badan menurut usia berdasarkan Z-score sama dengan atau kurang dari -2 SD di bawah rata-rata standar(1). Indonesia menduduki peringkat kelima dunia untuk jumlah anak dengan kondisi stunting dimana lebih dari sepertiga anak berusia dibawah lima tahun tingginya berada di bawah rata-rata (2). Perilaku pencegahan stunting yang tidak teratasi akan menyebabkan dampak jangka pendek yaitu angka kematian dan kesakitan meningkat dan jangka panjang yaitu penurunan prestasi belajar, kapasitas dan produktifitas kerja (3). Balita pendek atau stunting adalah suatu kondisi pada anak yang gagal tumbuh karena kekurangan zat gizi kronis sehingga menimbulkan anak menjadi lebih pendek untuk usianya.

Masalah gizi khususnya anak pendek (stunting), menghambat perkembangan anak dengan dampak negatif yang akan berlangsung dalam kehidupan selanjutnya. Anak-anak pendek menghadapi kemungkinan yang lebih besar untuk tumbuh menjadi orang dewasa yang kurang berpendidikan, miskin, kurang sehat dan lebih rentan terhadap penyakit tidak menular. Oleh 
karena itu, anak pendek merupakan prediktor buruknya kualitas sumber daya manusia yang diterima secara luas, yang selanjutnya menurunkan kemampuan produktif suatu bangsa dimasa yang akan datang (UNICEF, 2012).

Menurut World Health Organization (WHO), Prevalensi balita pendek menjadi masalah kesehatan masyarakat jika prevalensinya 20\% atau lebih. Dibandingkan beberapa negara tetangga, prevalensi balita pendek di Indonesia juga tertinggi dibandingkan Myanmar (35\%), Vietnam (23\%), Malaysia (17\%), Thailand (16\%) dan Singapura (4\%) (UNSD, 2014). Global Nutrition Report tahun (2014), Menunjukkan Indonesia termasuk dalam 17 negara, di antara 117 negara, yang mempunyai masalah gizi yaitu stunting (Kementerian Kesehatan, 2017)

Di Indonesia, Data Riset Kesehatan Dasar (Riskesdas, 2013), menunjukkan prevalensi balita stunting di Indonesia mencapai 37\% (terdiri dari 18\% sangat pendek dan 19,2\% pendek) yang berarti terjadi peningkatan tahun 2010 (35.6\%) dan tahun 2007 (36,8\%) prevalensi balita Pendek (Stunting). Di Provinsi Sulawesi Selatan mengalami peningkatan dari tahun 2007 $(29,1 \%)$ meningkat tahun 2010 (36,8\%) dan kembali mengalami peningkatan di tahun 2013 menjadi 40,9\% dan masih dipakai untuk menilai prevalensi balita stunting pada tahun 2014 dan belum mencapai target yang ditetapkan (34,5\%).

Angka ini juga menunjukkan bahwa posisi Sulawesi Selatan di tahun 2014 masih belum mencapai target Millennium Deploment Goals (MDGs) yaitu 32\%. Hasil Pemantauan Status Gizi (PSG) di Provinsi Sulawesi Selatan tahun 2015, terdapat dua daerah kabupaten yang paling tinggi kasus kejadian stunting yaitu Kabupaten Enrekang dan Kabupaten Bone. Sedangkan secara keseluruhan Stunting yang ada sebanyak 11 kabupaten Kota yang ada di kota Sulawesi Selatan itu adalah Kabupaten Enrekang, Bone, Pinrang, Gowa, Pankajene Kepulauan (Pangkep), Tana Toraja, Sinjai, Jeneponto, Toraja Utara, Takalar dan Kepulauan Selayar

Adapun tujuan penelitian ini adalah untuk mengetahui Pengetahuan Ibu yang berkaitan dengan pengendalian Stunting pada Balita dengan melihat pengetahuan pola Asuh, pengetahuan pola Makan Dan Sanitasi Lingkungan serta faktor yang mempengaruhinya.

\section{Hasil Penelitian}

1. Data Riskesdas Status Gizi Sangat Pendek dan Pendek Tahun 2013 dan 2018

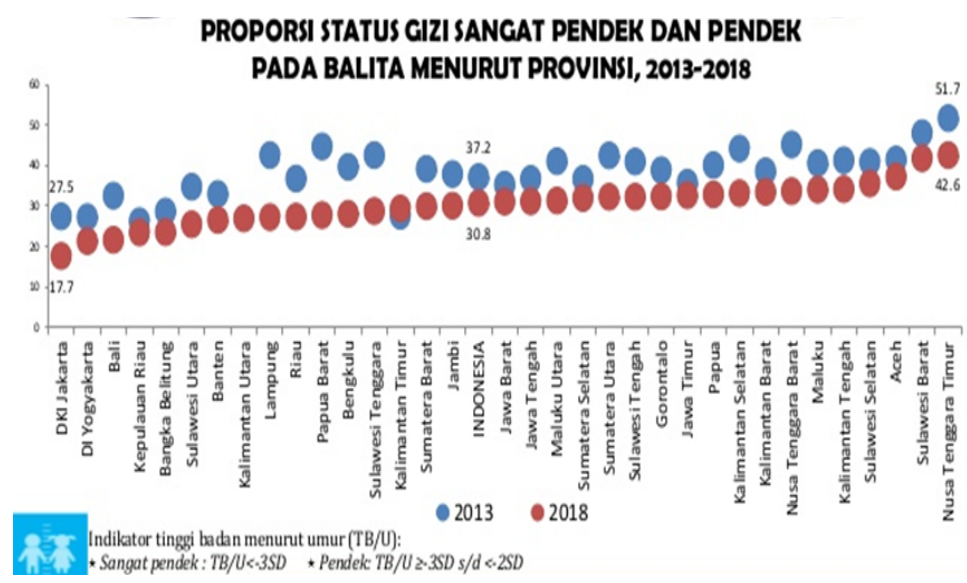

Sumber: Data Riskesdas 2018 
Kecenderungan Prevalensi Balita Pendek (Stunting) Provinsi Sulawesi Selatan mengalami peningkatan dari tahun 2007 (29,1\%) meningkat tahun 2010 (36,8\%) dan kembali mengalami peningkatan di tahun 2013 menjadi 40,9\% dan masih dipakai untuk menilai Prevalensi Balita Stunting pada tahun 2014 dan belum mencapai target yang ditetapkan (34,5\%). Angka ini juga menunjukkan bahwa posisi Sulawesi Selatan di tahun 2014 masih belum mencapai target MDGs yaitu 32\%. Namun hasil PSG di Provinsi Sulawesi Selatan tahun 2015 menunjukkan Prevalensi Balita Stunting mengalami penurunan yang cukup berarti yaitu sebesar $34,1 \%$. Berdasarkan hasil riset kesehatan penderita stunting Indonesia untuk, sementara untuk balita 30,1\%.

Indikator status gizi ini berdasarkan indeks $\mathrm{TB} / \mathrm{U}$ memberikan informasi mengenai indikasi masalah gizi yang sifatnya kronis sebagai akibat dari keadaan yang berlangsung lama. Seperti: kemiskinan, yang akan secara langsung dihubungkan dengan kesulitan material. perilaku hidup tidak sehat, dan pola asuh/pemberian makan yang kurang baik dari sejak anak dilahirkan yang mengakibatkan anak menjadi pendek Menurut World Health Organization/WHO batas maksimal stunting bayi adalah $20 \%$. Artinya stunting Balita di Indonesia saat ini masih di atas batas toleransi yang ditetapkan oleh Badan Kesehatan Dunia.

\section{Kemiskinan dan Stunting Di Kab/Kota Propinsi Sulawesi Selatan}

Kemiskinan menjadi masalah di hampir semua daerah di Indonesia. Padahal salah satu tujuan pembangunan nasional Indonesia adalah meningkatkan kinerja perekonomian agar mampu menciptakan lapangan kerja dan menata kehidupan yang layak bagi seluruh rakyat yang pada gilirannya akan mewujudkan kesejahteraan penduduk Indonesia melalui salah satu sasaran pembangunan nasional yaitu dengan menurunkan tingkat kemiskinan.

Provinsi Sulawesi Selatan merupakan salah satu daerah di Indonesia yang masih menghadapi permasalahan kemiskinan. Meski menjadi salah satu provinsi yang mempunyai tingkat pertumbuhan ekonomi cukup baik, angka kemiskinan di Provinsi Sulawesi Selatan masih terbilang cukup tinggi. Berdasarkan data resmi yang dirilis oleh BPS hingga akhir Desember 2014, penduduk dengan keadaan miskin di Provinsi Sulawesi Selatan mencapai 806.350 jiwa. Angka ini setara dengan 9,54 persen dari total penduduk yang bermukim di Provinsi Sulawesi Selatan. Jumlah penduduk miskin ini sebagian besar masih didominasi oleh daerah perdesaan yang mencapai 12,25 persen, sedangkan di perkotaan mencapai 4,93 persen (BPS dalam Saubani, 2015).

Keberadaan jumlah penduduk miskin di beberapa kabupaten/kota di Sulawesi Selatan yang masih relatif besar, dapat menegaskan bahwa kebijakan dan program penanggulangan kemiskinan yang diimplementasikan secara masif dalam beberapa tahun terakhir tampaknya tidak cukup efektif untuk memperbaiki taraf hidup penduduk miskin. 


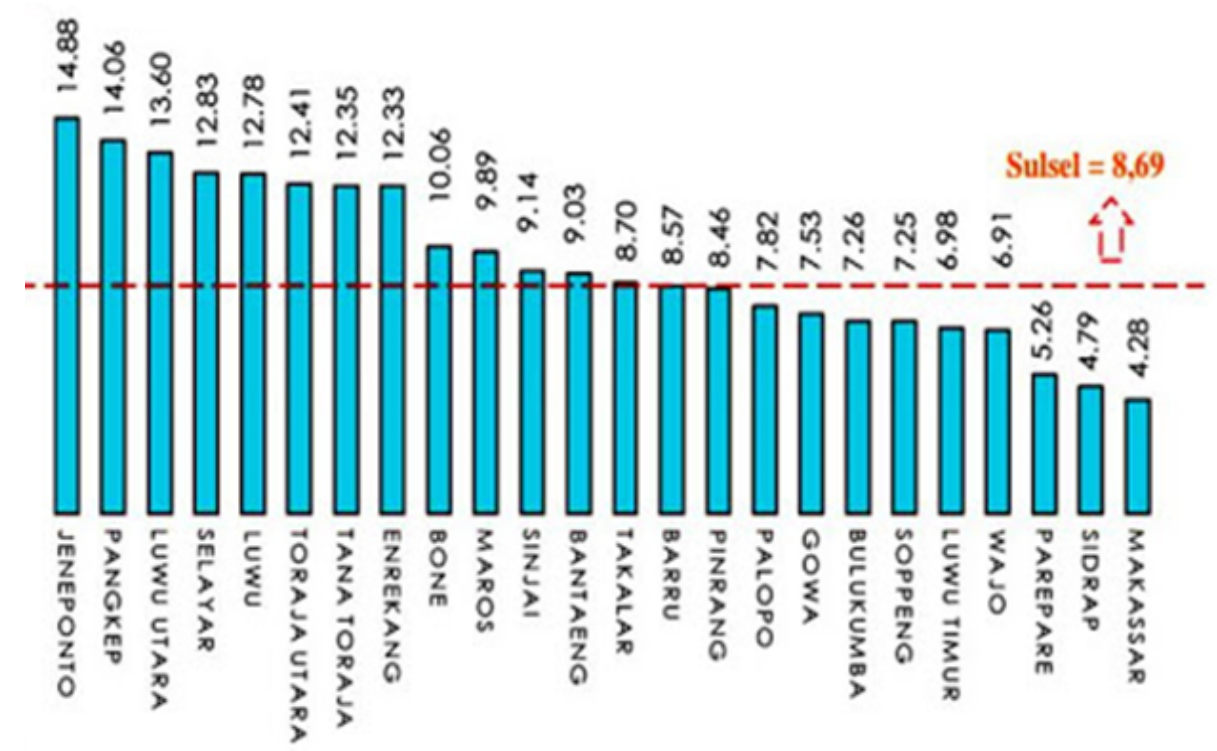

Sumber : Data BPS 2019

"Achmad Yurianto mengatakan, stunting atau kondisi gagal tumbuh pada anak disebabkan berbagai macam faktor. Salah satunya kemiskinan yang membuat sang ibu tidak dalam kondisi yang optimal saat kehamilan"(Republica, 10/2/20)

Status Sosial Ekonomi Keluarga, hasil pendapatan keluarga merupakan salah satu indikator sosial ekonomi keluarga lebih baik sehingga keluarga dapat mencukupi dan memenuhi kebutuhan konsumsi gizi dalam keluarga, didukung hasil penelitian yang menyatakan bahwa pendapatan keluarga yang rendah berisiko terhadap stunting (Kurnia Illahi 2017). penelitian yang juga dilakukan di 3 propinsi di Indonesia yaitu Bali, Jawa Barat dan NTT bahwa faktor risiko stunting salah satunya adalah pendapatan ayah yang rendah (Nadiyah, 2014). Hasil riset yang dilakukan di Kota Semarang menunjukkan bahwa tingkat social ekonomi keluarga yang rendah berisiko 11 kali mengalami stunting (AlAnshori,2013). Hasil riset di Propinsi Maluku menunjukkan variabel pendapatan keluarga yang rendah menjadi faktor risiko stunting (Agho, K. E.2009) bahwa penelitian yang dilakukan di India, Nepal, Ethiopia, dan Madagascar menyatakan bahwa faktor social ekonomi yang terkait dengan pendapatan dan kemiskinan berhubungan dengan stunting 31-35 ibu tidak bekerja juga berisiko 3,11 kali mengalami stunting .

\section{Pembahasan}

Stunting merupakan hasil dari kekurangan gizi kronis, yang menghambat pertumbuhan linear. Biasanya, pertumbuhan goyah dimulai pada sekitar usia enam bulan, sebagai transisi makanan anak yang sering tidak memadai dalam jumlah dan kualitas, dan peningkatan paparan dari lingkungan yang meningkatkan terkena penyakit. (Elizabeth, 2013). Menurut WHO (2010) stunting disebabkan oleh malnutrisi dan atau penyakit infeksi kronis yang berulang.

Kesehatan anak-anak dipengaruhi oleh suatu faktor, seperti pendapatan keluarga, pelayanan kesehatan, biologi, tingkah laku, dan sociocultural. Dengan memperhatikan fenomena 


\section{Muslimin B, Pengetahuan Ibu Balita Dalam Pengendalian Stunting}

yang ada, serta prevalensi mengenai Stunting serta pertumbuhan dan perkembangan nampaknya sangat berkorelasi dengan pola asuh, pola makan dan sanitasi lingkungan

\section{Pola Asuh}

Pola pengasuhan merupakan hal yang penting dalam proses tumbuh kembang anak. Salah satu faktor yang mempengaruhi pertumbuhan dan perkembangan anak adalah adanya faktor psikososial yang didalamnya mencakup hal penting dalam kehidupan anak yaitu pentingnya stimulasi dalam pengasuhan.Pola pengasuhan yang baik merupakan gambaran adanya interaksi positif anak dengan pengasuh utama yang berperan dalam perkembangan emosi dan psikologis anak sehingga menciptakan tumbuh kembang anak yang normal. (Turnip F. 2008)

Peran orang tua sedini mungkin akan menjalin rasa aman pada anaknya. Hal tersebut diwujudkan dengan kontak fisik dan psikologis sejak anak lahir hingga dalam proses tumbuh kembangnya. Kurangnya kasih sayang orang tua di tahun-tahun pertama berdampak negatif pada tumbuh kembang anak baik fisik, mental, maupun sosial emosi. Kasih sayang orang tua akan menciptakan ikatan yang erat (bonding) dan kepercayaan dasar (basic trust) (Soetjiningsih 1995). Disamping itu dengan pola asuh yang kurang baik tentunya akan timbul suatu permasalahan yang berkaitan dengan persoalan gizi bayi. Salah satu dukungan yang baik dari ibu bayi adalah pengetahuan tentang gizi, sehingga nantinya dapat memberikan ASI dan makanan pendamping yang sesuai akan kebutuhan bayi. Hal ini sejalan dengan penelitian Mustamin (2018) ini menunjukkan hasil signifikan atau bermakna dengan ibu balita yang memiliki pendidikan yang baik. Demikian pula pada penelitian Astari,(2008) bahwa Pengetahuan ibu tentang gizi berpengaruh pada perilaku ibu dalam menyediakan makanan bagi anaknnya. Ibu yang memiliki pengetahuan gizi baik diharapkan mampu menyediakan makanan dengan jenis dan jumlah yang tepat agar anak dapat tumbuh dan berkembang secara optimal Hal ini berarti ada hubungan antara tingkat pendidikan ibu dengan kejadian stunting pada balita di Provinsi Sulawesi Selatan Tahun 2015 berdasarkan analisis data sekunder Laporan Pemantauan Status Gizi (PSG) tahun 2015.

\section{Pola Makan}

Pemberian makan dengan cara yang sehat, pemberian makan bergizi dan mengatur porsi yang dihabiskan akan meningkatkan status gizi anak. Makanan yang baik untuk bayi dan balita harus memenuhi syarat-syarat kecukupan energi dan zat gizi sesuai umur, pola menu seimbang dengan bahan makanan yang tersedia, kebiasaan dan selera makan anak, bentuk dan porsi makanan yang disesuaikan pada kondisi anak dan memperhatikan kebersihan perorangan dan lingkungan (Handayani KOW, 2012). Ini sejalan dengan penelitian yang dilakukan di Kabupaten Bogor tahun 2005 yang menyebutkan praktek pemberian makan oleh ibu pada kelompok anak normal (tidak stunting) lebih baik dibandingkan pada kelompok anak stunting.(Saragih B. 2014)

Praktek pemberian makan tersebut antara lain meliputi frekuensi pemberian makan, pemberian makanan selingan, pertimbangan pemilihan jenis, pemberian makanan lengkap, penentuan waktu dan cara pemberian makan. Praktek pemberian makan yang kurang baik mengakibatkan anak tidak memperoleh asupan gizi seimbang dan secara kumulatif mengakibatkan gangguan pertumbuhan anak.(Astari, 2005) 
Beberapa penelitian lain yang menyebutkan pola asuh pemberian makan yang dilakukan ibu pada balita stunting sebagian besar kurang tepat dimana ibu tidak memperhatikan kebutuhan gizi balita. Ibu memberikan makanan mengikuti pola asuh makan keluarga dan memanfaatkan bahan makanan yang tersedia dalam rumah tangga. Pemberian makan balita hanya mengikuti kemauan anak, tanpa memaksakan makan atau tidak mencari variasi makanan lain.(Loya, 2017)

\section{Sanitasi Lingkungan}

Intervensi gizi saja belum cukup untuk mengatasi masalah stunting. Faktor sanitasi dan kebersihan lingkungan berpengaruh pula untuk kesehatan ibu hamil dan tumbuh kembang anak, karena anak usia di bawah dua tahun rentan terhadap berbagai infeksi dan penyakit. Paparan terus menerus terhadap kotoran manusia dan binatang dapat menyebabkan infeksi bakteri kronis. Infeksi tersebut, disebabkan oleh praktik sanitasi dan kebersihan yang kurang baik, membuat gizi sulit diserap oleh tubuh.

Rendahnya sanitasi dan kebersihan lingkungan pun memicu gangguan saluran pencernaan, yang membuat energi untuk pertumbuhan teralihkan kepada perlawanan tubuh menghadapi infeksi. Sebuah riset menemukan bahwa semakin sering seorang anak menderita diare, maka semakin besar pula ancaman stunting untuknya. Selain itu, saat anak sakit, lazimnya selera makan mereka pun berkurang, sehingga asupan gizi makin rendah. Maka, pertumbuhan sel otak yang seharusnya sangat pesat dalam dua tahun pertama seorang anak menjadi terhambat. Dampaknya, anak tersebut terancam menderita stunting, yang mengakibatkan pertumbuhan mental dan fisiknya terganggu, sehingga potensinya tak dapat berkembang dengan maksimal.

Penelitian lain menunjukkan potensi stunting berkurang jika ada intervensi yang terfokus pada perubahan perilaku dalam sanitasi dan kebersihan (Bhutta, ZA, 2008) Adapun akses terhadap sanitasi yang baik berkontribusi dalam penurunan stunting sebesar 27\%. (Fink, Günther 2011). Untuk memotong rantai buruknya sanitasi dan kebersihan serta kaitannya dengan stunting, ibu hamil dan anak perlu hidup dalam lingkungan yang bersih. Dua cara utama adalah dengan tidak buang air besar sembarangan, serta mencuci tangan dengan sabun.

Penelitian Spears et al. (2013) di India menyatakan bahwa perilaku sanitasi lingkungan yang buruk dalam hal kebiasaan buang air besar sembarangan (BABS) menjadi faktor penentu kejadian stunting. Stunting dapat dicegah de-ngan meningkatkan akses terhadap air bersih dan fasilitas sanitasi, serta menjaga kebersihan lingkungan. Anak dengan sanitasi lingkungan yang kurang akan memiliki peluang terjadinya stunting lebih besar dibandingkan anak dengan sanitasi lingkungan yang cukup dan baik

Ketersediaan air bersih berhubungan juga dengan kebiasaan dalam hal buang air besar. Kondisi curah hujan yang rendah dan kondisi geografis yang sulit menambah keterbatasan masyarakat untuk mendapatkan akses air bersih, sehingga air menjadi bahan yang sulit didapat di daerah pegunungan. Air yang bersih mencegah perkembangan 


\section{Muslimin B, Pengetahuan Ibu Balita Dalam Pengendalian Stunting}

penyakit yang secara bersama-sama dengan sanitasi dan kebersihan memengaruhi kesehatan status gizi terutama gizi kurang (Kavosi et al. 2014).

\section{Kesimpulan}

Berdasarkan hasil identifikasi dan telaah beberapa artikel dapat disimpulkan bahwa risiko terjadinya stunting di Sulawesi Selatan secara konsisten adalah status social ekonomi atau hal yang terkait dengan kemiskinan keluarga. Selain itu dipengaruhi pula terhadap Pola asuh dalam keluarga berupa kebiasaan pengasuhan pemberian kasih sayang, kepedulian terhadap kebersihan anak,interaksi psikologis anak,sedangkan pola makan dengan kebiasaan pemberian makan, kebiasaan kebersihan dilingkungannya maupun untuk diri ibu balita tentu akan mempengaruhi akan pengasuhan kepada anaknya baik pada lingkunga keluarga maupun dan kebiasaan mendapatkan pelayanan kesehatan diposyandu maupun layan kesehatan lainnya yang erat kaitannya dengan kejadian stunting balita.

Permasalahan gizi balita yang stunting tidak mutlak juga terjadi pada keluarga kurang mampu/miskin tetapi lebih disebabkan oleh peranan pola asuh yaitu kebiasaan pemberian makan, kebiasaan pengasuhan, kebiasaan kebersihan. Perbaikan permasalahan gizi dengan pemberdayaan masyarakat dengan pendekatan upaya peningkatan pengetahuan masyarakat melalui upaya-upaya preventif dan promotif dengan merubah kebiasaan-kebiasana keluarga yang kurang baik dan mengambil manfaat secara positifyang dilakukan ibu balita dalam rangka meningkatkan status gizi balita.

\section{Saran}

1. Penanganan stunting diperlukan intervensi yang tepat dalam penangan-annya seperti peningkatan penyuluhan, konse-ling dan pembelajaran kepada masyarakat dimana di harapkan kepada petugas/penyuluh dapat meningkatkan pembinaan kader posyandu dalam hal praktik higiene perorangan dan praktik kasih sayang dan melakukan upaya monitoring terhadap pertumbuhan balita sehingga dapat mengurangi risiko terjadinya stunting pada balita.

2. Peningkatan kapasitas masyarakat melalui kegiatan yang dapat memberikan pengetahuan tentang pemberian makanan dan pengelolaan makanan yang baik terhadap pertumbuhan dan perkembangan balita.

3. Perlunya pendampingan atau konseling terhadap peran serta masyarakat dalam program kesehatan yang berkaitan lingkungan sehingga memungkinkan terciptanya kondisi sanitasi lingkungan yang baik dan terhindar dari ancaman penyakit infeksi yang bersumber dari lingkungan. 


\section{Referensi}

Al-Anshori, H. \& Nuryanto, N. (2013). FAKTOR RISIKO KEJADIAN STUNTING PADA ANAK USIA 12-24 BULAN (Studi di Kecamatan Semarang Timur). J. Nutr. Coll. 2, $675-681$.

Astari, LD. 2008. Faktor-faktor yang Berpengaruh Terhadap Kejadian Stunting Balita Usia 6-12 Bulan di Kabupaten Bogor (Tesis). Institut Pertanian Bogor : Bogor.

Agho, K. E., Inder, K. J., Bowe, S. J., Jacobs, J. \& Dibley, M. J. (2009). Prevalence and risk factors for stunting and severe stunting among under-fives in North Maluku province of Indonesia. 10, 1-10.

Bhutta, ZA, Ahmed, T., Black, RE. (2008). Maternal and Child Undernutrition 3: What Works? Interventions for Maternal andChild Undernutrition and Survival. Lancet: 371: 417-40

Astari LD, Nasoetion A, Dwiriani C. (2005). Hubungan Karakteristik Keluarga, Pola Pengasuhan dan Kejadian Stunting Anak Usia 6-12 Bulan. Media Gizi dan Keluarga. 29(2) : 40-46.

Elizabeth. 2013. Gambaran sosial ekonomi keluarga anak balita pendek (stunting) dikelurahan sudiang raya kecamatan biringkanaya kota makassar. Karya Tulis Ilmiah. Jurusan Gizi Politeknik Kesehatan Makassar Program studi diploma III Gizi.

Fink, Günther, Isabel Günther, and Kenneth Hill. (2011). "The effect of water and sanitation on child health: evidence from the demographic and health surveys 1986-2007." International journal of epidemiology 40.5: 1196-1204.

Handayani KOW, Prameswari GN. (2012). Daerah Positive Deviance Sebagai Rekomendasi Model Perbaikan Gizi. Jurnal Kesehatan Masyarakat. 7(2) : 102-109.

Kementerian Kesehatan. (2017). Data dan Informasi Profil Kesehatan Indonesia. Kementerian Kesehatan RI.

Kavosi E, Rostami ZH, Kavosi Z, Nasihatkon A, Moghadami M, Heidari M. 2014. Prevalence and determinants of under-nutrition among children under six: a cross-sectional survey in Fars province. Iran Int J Health Policy Manag 3(2):71-76.

Kurnia Illahi, R. (2017). Hubungan Pendapatan Kelarga, Berat Lahir, dan Panjang Lahir dengan Kejadian Stunting balita 24-59 bulan di Bangkalan. Manaj. Kesehat. Yayasan RS Dr. Sietomo 3, 1-14.

Loya RRP, Nuryanto. (2017). Pola Asuh Pemberian Makan pada Balita Stunting usia 6-12 bulan di kabupaten Sumba Tengah Nusa Tenggara Timur. Journal of Nutrition College. 6(1) : 83-95. 
Muslimin B, Pengetahuan Ibu Balita Dalam Pengendalian Stunting

Mustamin, dkk, 2018, Tingkat Pendidikan Ibu Dan Pemberian Asi Eksklusif Dengan Kejadian Stunting Pada Balita Di Provinsi Sulawesi Selatan, Media Gizi Pangan, Vol. 25, Edisi 1,

Nadiyah. (2014). Faktor Risiko Stunting Pada Anak Usia 0-23 Bulan Di Provinsi Bali, Jawa Barat, Dan Nusa Tenggara Timur. J. Gizi dan Pangan 9, 125-132.

Saubani, A. (2015). 806.350 Rakyat Miskin Tinggal di Sulsel. Makassar: Republika

Saragih B. (2014). Analisis Perilaku Positif Deviance Pemberian Makan dan Ketahanan Pangan Keluarga Miskin (Positive Deviance Analysis of Feeding Behavior and Food Security of Poor Families). Magrobis Journal. 14(1):1-2.

Spears D, Ghosh A, Cumming O. 2013, Open defecation an childhood stunting in India: an ecological analyisis of new data form 112 district, Journal PLoS ONE

Soetjiningsih. Tumbuh Kembang Anak. Jakarta: Penerbit Buku Kedokteran EGC. 1995

Turnip F. (2008). Pengaruh Positive Deviance pada Ibu dari Keluarga Miskin Terhadap Status Gizi Anak Usia 12-24 bulan di Kecamatan Sidikalang Kabupaten Dairi Tahun 2007 (Thesis). Medan : Universitas Sumatera Utara. 